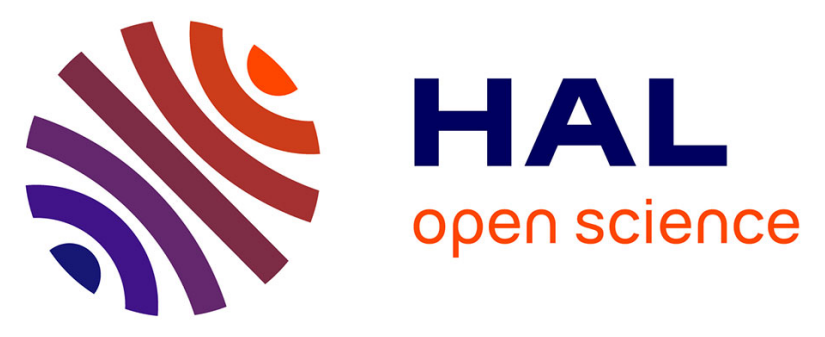

\title{
De novo TUBB2B mutation causes fetal akinesia deformation sequence with microlissencephaly: an unusual presentation of tubulinopathy
}

Annie Laquerrière, Marie Gonzales, Yoann Saillour, Mara Cavallin, Nicole Joyē, Chloé Quēlin, Laurent Bidat, Marc Dommergues, Ghislaine Plessis, Ferechte Encha-Razavi, et al.

\section{To cite this version:}

Annie Laquerrière, Marie Gonzales, Yoann Saillour, Mara Cavallin, Nicole Joyē, et al.. De novo TUBB2B mutation causes fetal akinesia deformation sequence with microlissencephaly: an unusual presentation of tubulinopathy. European Journal of Medical Genetics, 2015, 59 (4), pp.249-256. 10.1016/j.ejmg.2015.12.007 . hal-01259440

HAL Id: hal-01259440

https://hal-univ-rennes1.archives-ouvertes.fr/hal-01259440

Submitted on 6 Jun 2016

HAL is a multi-disciplinary open access archive for the deposit and dissemination of scientific research documents, whether they are published or not. The documents may come from teaching and research institutions in France or abroad, or from public or private research centers.
L'archive ouverte pluridisciplinaire HAL, est destinée au dépôt et à la diffusion de documents scientifiques de niveau recherche, publiés ou non, émanant des établissements d'enseignement et de recherche français ou étrangers, des laboratoires publics ou privés. 
1 De novo TUBB2B mutation causes fetal akinesia deformation sequence with

\section{microlissencephaly: an unusual presentation of tubulinopathy}

Running Title: Fetal akinesia sequence due to TUBB2B mutations

Annie LAQUERRIERE (1,2), Marie GONZALES (3,4), Yoann SAILlOUR (5-7), Mara CAVALLIN (7-9), Nicole JOYĒ (3,4), Chloé QUĒLIN (10), Laurent BIDAT (11), Marc

DOMMERGUES (4,12), Ghislaine PLESSIS (13), Ferechte ENCHA-RAZAVI $(7,8,14)$, Jamel CHELLY (15,16), Nadia BAHI-BUISSON (7-9)*, Karine POIRIER(5-7)*

* Both authors contributed equally to the manuscript

\section{AFFILIATIONS:}

1 - Pathology Laboratory, Rouen University Hospital, France

2- Region-Inserm Team NeoVasc ERI28, Laboratory of Microvascular Endothelium and Neonate Brain Lesions, Institute of Research Innovation in Biomedecine, Normandy University, Rouen, France

3 - Department of Medical Genetics, Armand Trousseau Hospital, APHP, Paris, France 4 - Sorbonne Universities, UPMC, Paris, France

5 - Inserm, U1016, Institut Cochin, Paris, France

6- CNRS, UMR8104, Paris, France

7 - Paris Descartes - Sorbonne Paris Cité University, Imagine Institute, Paris, France 8-Pediatric Neurology, Necker Enfants Malades University Hospital, Paris, France 9- INSERM UMR-1163, Embryology and genetics of congenital malformation Université Paris Descartes-Sorbonne Paris Cité, Institut Imagine, Université Paris Descartes-Sorbonne Paris Cité, France 10-Department of Clinical Genetics, South University Hospital, Rennes, France 11 - Department of Prenatal Diagnosis, Department of Obstetrics and Gynecology, René Dubos Hospital, Pontoise, France

12 - Department of Obstetrics and Gynecology, Groupe Hospitalier Pitié Salpêtrière, APHP, Paris, France 13 - Department of Genetics, Clinical Genetics, Caen University Hospital, Caen, France 
3114 - Département de Génétique, Necker-Enfants Malades University Hospital, Paris, France 15 - Pôle de biologie, Hôpitaux Universitaires de Strasbourg, Strasbourg, France

3216 - Institut de Génétique et Biologie Moléculaire et Cellulaire - IGBMC, INSERM, CNRS,

33 Université de Strasbourg, Strasbourg, France

34

35

36 Corresponding author's information

37 Nadia Bahi-Buisson, $\mathrm{MD}, \mathrm{PhD}$

38 Université Paris Descartes-Sorbonne Paris Cité, Institut Imagine-INSERM UMR-1163,

39 Embryology and genetics of congenital malformations

40 Email: nadia.bahi-buisson@nck.aphp.fr

$41 \quad$ Phone +33142192699

$42 \quad$ Fax +33142192692

43

\section{Clinical Report}

45 Word Count for the abstract 166

46 Word Count for the text 2515

47 Character count for the title 16

48 Number of figures 5

49 Supplementary figures : 2

50 References 26 
52

ABSTRACT

53

2 KEY WORDS sequence

Tubulinopathies are increasingly emerging major causes underlying complex cerebral malformations, particularly in case of microlissencephaly often associated with hypoplastic or absent corticospinal tracts. Fetal akinesia deformation sequence (FADS) refers to a clinically and genetically heterogeneous group of disorders with congenital malformations related to impaired fetal movement.

We report on an early foetal case with FADS and microlissencephaly due to TUBB2B mutation. Neuropathological examination disclosed virtually absent cortical lamination, foci of neuronal overmigration into the leptomeningeal spaces, corpus callosum agenesis, cerebellar and brainstem hypoplasia and extremely severe hypoplasia of the spinal cord with no anterior and posterior horns and almost no motoneurons.

At the cellular level, the p.Cys239Phe TUBB2B mutant leads to tubulin heterodimerization impairment, decreased ability to incorporate into the cytoskeleton, microtubule dynamics alteration, with an accelerated rate of depolymerization.

To our knowledge, this is the first case of microlissencephaly to be reported presenting with a so severe and early form of FADS, highlighting the importance of tubulin mutation screening in the context of FADS with microlissencephaly.

3 microlissencephaly, microcephaly, migration disorder, $T U B B 2 B$, Fetal akinesia deformation 


\section{INTRODUCTION}

Normal fetal development is dependent on adequate fetal movement, starting at 8 weeks of gestation (WG). Limitation of movements results in fetal akinesia deformation sequence (FADS; OMIM 208150). FADS was first reported as a syndrome by Pena and Shokeir in 1974 and further delineated as a symptom by Hall in 1981 [1,2]. Its incidence varies among different countries and has been estimated at 1:3000 to 1:5000 by Fahy and Hall [3]. The clinical presentation is highly variable, ranging from the most severe form called lethal multiple pterygium syndrome characterized by multiple joint contractures and pterygia, lung hypoplasia, short umbilical cord, craniofacial changes consisting of hypertelorism, micrognathism, cleft palate, short neck, low-set ears, along with intrauterine growth retardation and abnormal amniotic fluid volume mainly observed from the first trimester of the pregnancy [4]. Less severe phenotypes may present either as distal arthrogryposis or as fetal hypomotility which usually occurs during the third trimester [5].

Non-genetic factors may cause FADS, such as environmental limitation of fetal movements, maternal infection, drugs and immune mechanisms (maternal autoimmune myasthenia). The FADS phenotype is observed in a number of known genetic syndromes. Non syndromic or isolated FADS is genetically heterogeneous and encompass multiple neurogenic processes affecting the central or the peripheral nervous system, the neuromuscular junction and the skeletal muscle [6-8]. Until recently, the neurogenic form characterized by spinal cord motoneuron paucity, either isolated or associated with pontocerebellar hypoplasia was considered as the most frequent cause [9-11]. Conversely, brain malformations are very infrequently observed in association with FADS, and mainly described in lissencephalies type I and II as deformations of the extremities $[12,13]$. To our knowledge, FADS has never been reported in association with tubulin related cortical malformations. Here, we report on the most severe presentation of tubulinopathy in a fetus harboring a de novo missense mutation in 
100 the $\beta$-tubulin gene TUBB2B gene (MIM 615101), along with neuropathology and molecular

101 data focusing on the consequences of the mutation, that could explain at least partly the

102 severity of the lesions and early fetal presentation.

\section{PATIENT AND METHODS}

\section{Case history}

105 A 32-year-old woman, gravida 4, para 3, underwent routine ultrasonography (US) at 12 WG, 106 which revealed severe fetal akinesia. Control ultrasound examination performed at 14 WG 107 confirmed total lack of movements, retrognathia and dilatation of the third and fourth cerebral 108 ventricles (supplementary figure 1). A medical termination of the pregnancy was achieved at $10915 \mathrm{WG}$, in accordance with French law. A complete autopsy was performed with informed

110 written consent from both parents. Brain lesions identified at autopsy suggested a possible

111 Walker Warburg syndrome (WWS) despite absent eye lesions, so that a first-line screening of

112 WWS genes was performed, but was negative. Indeed, known environmental causes of FADS

113 were excluded, as well as syndromic causes. Chromosomal analysis performed on trophoblast

114 biopsy revealed a normal male karyotype, 46, XY. The parents were non consanguinous and

115 there was no relevant personal or family history. Three children born to a previous marriage

116 were in good health.

117 After having obtained written informed consent from the parents, DNAs were purified from

118 fetal lung tissues, and from peripheral blood cells in both parents by using a standard 119 phenol/chloroform method. Mutation analysis was performed by PCR amplification and 120 direct SANGER sequencing of all coding exons and splice sites of the TUBB2B gene revealed

121 a de novo missense mutation in exon 4, c.716G $>$ T determining a p.Cys239Phe substitution 122 (previously reported in [14]). No other variant was identified after sequencing of the other 123 genes involved in cortical malformations.

\section{Neuropathological evaluation}


125 Tissues including the brain, eyes and spinal cord were fixed in a $10 \%$ formalin-zinc buffer

126 solution. Seven-micrometer sections obtained from paraffin-embedded tissues were stained

127 using Haematoxylin-Eosin. Adjacent brain and spinal cord sections were assessed for routine

128 immunohistochemistry, using antibodies directed against vimentin (diluted 1:100; Dakopatts,

129 Trappes, France), calretinin (1:200; Zymed Clinisciences, Montrouge, France), and MAP2

130 (diluted 1:50, Sigma, St Louis, MO). Immunohistochemical procedures included a microwave

131 pre-treatment protocol to aid antigen retrieval (pretreatment CC1 kit, Ventana Medical

132 Systems Inc, Tucson AZ). Incubations were performed for 32 minutes at room temperature

133 using the Ventana Benchmark XT system. After incubation, slides were processed by the

134 Ultraview Universal DAB detection kit (Ventana). All immunolabellings were compared with

135 an age matched control case examined after a spontaneous abortion for premature rupture of

136 the membranes, and whose brain was histologically normal.

137 Functional analyses

$138 \quad$ Protein modeling

139 A model of human $\beta$-tubulin was built by homology modeling using available structures

140 (Research Collaboratory for Structural Bioinformatics PDB code 1TUB) from Nogales et al.

141 [15]. The images in Figure 4C were rendered using PyMOL software

142 (http://www.pymol.org).

\section{Cloning and in vitro translation}

144 TUBB2B sequence was generated by PCR using a template from the human brain cDNA

145 library (Clontech, Mountain View, CA). The PCR product was cloned into the pcDNA 3.1-

146 V5-His vector (Invitrogen, Carlsbad, CA) and checked by DNA sequencing. These products

147 were cloned both into the cDNA3.1-V5-his-TOPO-TA cloning vector (Invitrogen) and pET

148 vector. An in-frame tag encoding the FLAG epitope (DYKDDDDK) was incorporated by

149 PCR along with the C-terminus of the TUBB2B wild-type sequence allowing for the 
150 distinction of the transgene from other highly homologous endogenously expressed $\beta$-tubulin

151 polypeptides. The p.Cys239Phe mutation was introduced by site-directed mutagenesis using a

152 QuikChange II kit (Stratagene, La Jolla, CA) and verified by DNA sequencing.

153 Transcription/translation reactions were performed at $30^{\circ} \mathrm{C}$ for $90 \mathrm{~min}$ in $25 \mu \mathrm{l}$ of rabbit

154 reticulocyte lysate (TNT; Promega, Madison, WI) containing ${ }^{35}$ S-methionine (specific

155 activity, $1000 \mathrm{Ci} / \mu \mathrm{mol} ; 10 \mu \mathrm{Ci} / \mu \mathrm{l})$. For the generation of labelled $\beta$-tubulin heterodimers,

156 transcription/translation reactions were chased for a further $2 \mathrm{~h}$ at $30^{\circ} \mathrm{C}$ by the addition of

$1570.375 \mathrm{mg} / \mathrm{ml}$ of native bovine brain tubulin. Aliquots $(2 \mu 1)$ were withdrawn from the

158 reaction, diluted into $10 \mu 1$ of gel-loading buffer (gel running buffer supplemented with $10 \%$

159 glycerol and $0.1 \%$ bromophenol blue) and stored on ice prior to resolution on a non-

160 denaturing gel. Labeled reaction products were detected by autoradiography after resolution

161 on either SDS-PAGE or on native polyacrylamide gels as described $[16,17]$.

162 Cell cultures, transfections and immunofluorescence

163 Primary cultures of fibroblasts were derived from fibroblastic cells extracted from amniotic

164 liquid. COS7 and Hela cells were transfected by construct with p.Cys239Phe TUBB2B

165 mutation using the Fugene 6 transfection reagent (Roche Applied Science, Indianapolis, IN)

166 and grown on glass cover slips in Dulbecco's modified Eagle's medium containing 10\% fetal

167 calf serum and antibiotics. The cells were fixed with ice-cold methanol, 24-48h after growth.

168 In the depolymerization experiments used to determine the behavioural stability of

169 microtubules after $24 \mathrm{~h}$ of culture, fibroblasts were incubated for various brief intervals from

$170 \quad 0$ to $30 \mathrm{~min}$ on ice and fixed thereafter. Repolymerization experiments were performed by

171 successively exposing cells at $4^{\circ} \mathrm{C}$ during $30 \mathrm{mn}$ and fixed after being incubated from 0 to 15

$172 \min$ at $37^{\circ} \mathrm{C}$. Cells were then labelled with a polyclonal anti-FLAG antibody $(1 / 500)$, or a

173 monoclonal anti- $\alpha$-tubulin antibody (1/1000) (Sigma-Aldrich Inc., St Louis, MO). At each

174 experimental point, two parameters were quantified using ImageJ software: (i) the total area 
175 of the cell and (ii) the area of the microtubules network of each cell, evaluated by

176 quantifying the alpha-tubulin staining into the cytoskeleton and excluding the staining

177 background corresponding to unincorporated alpha tubulin into the cellular cytoplasm. The

178 ratio Microtubules Area/Total cell Area was used to evaluate the state of the microtubule

179 network of the patient and control cells at each time point of

180 depolymerisation/repolymerization experiments.

RESULTS

\section{General autopsy findings}

185 The fetus weighed $47 \mathrm{~g}\left(50^{\text {th }}\right.$ centile $)$. External examination disclosed cranio-facial

186 dysmorphism with microretrognathia and cleft palate due to akinesia (supplementary figure

187 2), global amyotrophy and microcephaly (Figure 1A). No internal visceral malformation was

188 found, except for the lungs which were hypoplastic, and the renal pelvis which was dilated.

\section{Neuropathological studies}

190 Macroscopically, the brain appeared to be small, weighting $2.15 \mathrm{~g}\left(5^{\text {th }}\right.$ centile, normal weight

$191=10 \mathrm{~g}$ according to Guilhard-Costa and Larroche [18]). Occipito-frontal length was $21 \mathrm{~mm}$ and

192 transverse diameter of the cerebellum was $0.17 \mathrm{~mm}\left(25^{\text {th }}\right.$ centile). The brain surface was

193 smooth, covered by thickened leptomeninges adherent to the brain (Figure 1B). Olfactory

194 tracts were absent and the meninges seemed fused (Figure 1C). On brainstem sections, the

195 fourth ventricle was dilated and the cerebellum seemed hypoplastic and dysplastic,

196 resembling the cerebellar dysplasia observed in Walker Warburg syndrome (Figure 1D).

197 Macroscopic examination of serial coronal sections confirmed the dilatation of the third and

198 lateral ventricles, the latter being filled with congestive choroid plexuses. 
199 Histological examination of the eyes revealed no retinal dysplasia. The spinal cord displayed

200 major lesions consisting of severe hypoplasia and immaturity (Figure 2A). Ascending and

201 descending tracts were missing. Anterior and posterior horns were hardly discernible, with

202 almost no motoneurons in the anterior horns, even using MAP2 antibodies (data not shown)

203 (Figure 2B). The cerebral mantle was particularly thin, and cortical lamination was absent,

204 rather forming an extremely disorganized two-layered cortex extending from the inferior limit

205 of the marginal zone to the periventricular zone with no recognizable intermediate zone

206 (Figure 2C). Layer I was irregular in width and contained isolated or small foci of immature

207 neurons, as well as misplaced Cajal-Retzius cells immunolabeled by calretinin antibody lying

208 under the pial basal membrane (Figure 2D). Underneath, a single band of neurons with a

209 vague nodular or columnar organization was found, extending to the periventricular areas

210 (Figure 2E). The cerebral mantle was covered by fibrous meninges containing multiple

211 dysplastic tortuous vessels with dispersed overmigrating immature neurons (Figure 2F).

212 Vimentin immunohistochemistry showed an irregular and fragmented glia limitans (Figure

213 3A and B), with small gaps through which neurons overmigrated into the leptomeningeal

214 spaces (Figure 3C, D). Vimentin immunohistochemistry also revealed severe abnormalities of

215 the radial glia, which virtually absent in the cortical plate and entirely disorganized in the

216 subventricular zone (Figure 3E and F).

217 Functional analyses

218 Consequences of the mutation on secondary and tertiary TUBB2B structures

219 The p.Cys239 residue is located in the intermediary domain (amino acid 205-381) of the

220 TUBB2B protein and is highly conserved during evolution among TUBB2B homologues

221 from other species (Figure 4A). Tridimensional modeling analysis of TUBB2B using PYmol

222 software displayed an inside localization of the variant in an helix closed to the Taxol fixation 
site, apparently affecting neither the GDP binding pocket nor the $\alpha / \beta$ interacting region

224

225

226 (Figure 4B).

Alteration of $\alpha / \beta$ heterodimerization process and microtubules incorporation by TUBB2B variant

To further investigate functional consequences of the mutation, the $\beta$-tubulin mutant was expressed in rabbit reticulocyte lysate and its ability to assemble into $\alpha / \beta$ heterodimers in the presence of bovine brain tubulin was evaluated. The p.Cys239Phe mutant was translated as efficiently as the wild-type control (Figure 5A). However, analysis of the same reaction products under native conditions revealed a range of heterodimer formation that was significantly decreased both quantitatively and qualitatively in the case of p.Cys239Phe mutant compared to the wild-type control (Figure 5B) revealing an impairment of tubulin heterodimerization processes in the p.Cys239Phe mutant.

Furthermore, the transfection of the flag-tagged p.Cys239Phe TUBB2B-mutated construct in COS7 and HeLa cells revealed both a detectable incorporation of the protein into microtubules and in contrast to controls, a diffuse high background of label that reflects presence of unpolymerized cytosolic tubulin heterodimers, suggesting a partial impairment of the remaining heterodimer ability to incorporate into the cytoskeleton (Figure 5C).

Effects of p.Cys239Phe TUBB2B mutation on the dynamical microtubule behavior in fetal fibroblasts

In order to assess the behavior of the microtubules in vivo, we analyzed the response of the cytoskeleton to cold-induced depolymerization treatment followed by a repolymerization step at $37^{\circ} \mathrm{C}$ in fibroblasts extracted from amniotic liquid from control and affected patient.

Following cold-induced depolymerization, TUBB2B p.Cys239Phe displayed a normal rate of microtubules disintegration (Figure 5C). However, repolymerization experiments, consisting in a completed cytoskeleton depolymerization at $4^{\circ} \mathrm{C}$ and a gradual repolymerisation at $37^{\circ} \mathrm{C}$, 
248 revealed that p.Cys239Phe TUBB2B mutant microtubules are more repolymerized after

$2495 \mathrm{~min}$ at $37^{\circ} \mathrm{C}$ than controls (Figure 5C). These experiments show that with p.Cys239Phe

250 mutant, the repolymerization rate to renew its cytoskeleton network is accelerated, provoking

251 a defect of the depolymerization/repolymerization balance necessary for a proper dynamic

252 behaviour of microtubules.

\section{DISCUSSION}

254 We report here the first case of Fetal Akinesia Deformation Sequence with 255 microlissencephaly related to $T U B B 2 B$ mutation, expanding the phenotype of ever-growing 256 family of tubulin associated malformations. The diagnosis of FADS can be approached 257 algorithmically, based on the presence of neurological symptoms and associated features $258[19,6]$. Developmental abnormalities affecting the forebrain (e.g., hydranencephaly, 259 microcephaly, or forebrain neuronal migration disorders), either due to primary genetic 260 factors or to a consequence of fetal central nervous system infection or vascular insult, are 261 sometimes associated with arthrogryposis [6,20]. In such cases, joint contractures are thought 262 to be related to diminished corticospinal tract activation of spinal cord motor neurons. 263 Sometimes, however, the underlying disease also directly affects spinal cord motor neurons, 264 contributing to fetal akinesia or hypomotility. In addition to these classical causes, our report 265 demonstrates that tubulin related microlissencephaly should be considered within the 266 algorithm for diagnosis.

267 Microlissencephaly is a rare entity characterized by severe congenital microcephaly with 268 absent sulci and gyri leading most of the time to an early fatal outcome during the foetal or 269 the neonatal period. We have previously underlined the importance of microlissencephaly in 270 the spectrum of tubulinopathies [14]. There are emerging molecular data to suggest that 271 NDE1 mutations [21,22] and more recently KATNB1 mutations [23] are involved in the 272 autosomal recessive forms. Tubulin mutations, particularly TUBA1A and less frequently 
273 TUBB2B and TUBB3 are significant causes of sporadic cases of microlissencephaly.

274 Tubulin related microlissencephaly share common features consisting in corpus callosum

275 agenesis, extremely reduced or absent cortical plate, hypertrophic germinal zones and

276 ganglionic eminences, hypoplastic and disorganized striatum and thalami. In our case, the

277 striatum and thalami were absent, along with germinative zones in which radial glial cells and

278 radial glia had early disappeared, representing the most severe end of the spectrum. At the 279 infratentorial level, our case also showed common signs of tubulin related 280 microlissencephaly, i.e. severe cerebellar and brainstem hypoplasia, axon tract defects with 281 absent corticospinal tracts. To our knowledge, 13 foetal cases with tubulin related 282 microlissencephaly [14,24] and 4 living patients [24,25] have been reported so far. Of these, 8 283 exhibited non specific dysmorphic features including retrognathia and hypertelorism, as well 284 as adducted thumbs, extremely long fingers, and rocker bottom feet related to poor fetal 285 mobility. The case reported here represents the extreme severe end of the spectrum due to 286 extremely severe spinal cord hypoplasia with absent anterior and posterior horns and virtually 287 indiscernible motoneurons at the histological level. In this context, fetal akinesia deformation 288 sequence undoubtedly represents a neurogenic form, reminiscent of akinesia observed in 289 Spinal Muscular Atrophy or fetal Pontocerebellar Hypoplasia type 1 [9-11].

290 The precise molecular function of TUBB2B in cortical development still remains unclear. Our 291 analysis suggests that the aminoacid substitution in the p.Cys239Phe TUBB2B mutant leads 292 to an impairment of tubulin heterodimerization processes and heterodimer ability to 293 incorporate into the cytoskeleton. Morever, this mutant alters the microtubule dynamics with 294 an accelerated rate of repolymerization, that is has been also predicted with another TUBB2B 295 related microlissencephaly mutation (p.Asp249His) [26]. In the literature, we already 296 demonstrated that two TUBA1A and TUBB2B mutants' cells p.Pro263Thr and p.Ser172Pro, 297 respectively) display an opposite phenotype consisting of a defect to renew their cytoskeleton 
network after total depolymerization, we assume that the two types of repolymerization impairments lead to abnormalities of the depolymerization/repolymerization balance

300 necessary for a proper dynamic behaviour of microtubules [27,28]. As suggesting in the

301 literature, a default in microtubules dynamics could lead to dramatic impairments of a 302 numerous cellular processes including proliferation, migration and differentiation that are 303 crucial steps for the brain development $[28,29,30]$. Therefore, we assume that this alteration 304 of microtubule dynamics might affect brain and spinal cord development at distinct 305 developmental steps, i.e. neurogenesis, neuronal migration and long tract formation, leading 306 to the association of FADS and microlissencephaly. According to structural molecular 307 models, the mutant p.Cys239Phe is predicted to alter tubulin folding. This extreme phenotype 308 contrasts with our previous observations in which tubulin mutations predicted to impair 309 tubulin folding but tended to be associated with milder cortical malformations [26] and 310 emphasizes on the fact that comprehensive overview of tubulinopathies spectrum will require

311 further investigations, including understanding of spatial and temporal consequences of 312 tubulin mutations on MT-dependent cellular functions and early neuro-developmental 313 processes.

314 In conclusion, this fetal case recapitulates the phenotypic features of tubulin related 315 microlissencephaly expands the phenotype due to early severe arthrogryposis and underlines 316 the importance of considering tubulin gene $T U B B 2 B$ in the diagnosis of arthrogryposis with 317 microlissencephaly.

\section{AKNOWLEDGMENTS}

319 We would like to thank Prof. Beldjord for their careful reading and constructive comments,

320 Dr Lascelles for her advice on improving the manuscript, and Dr Sandrine Vuillaumier-Barrot 321 and Odile Philippon. The research leading to these results was funded by the European Union 
322 Seventh Framework Programme FP7/2007-2013 under the project DESIRE (grant

agreement $\left.\mathrm{n}^{\circ} 602531\right)$. KP, NBB and JC were supported in part by a « Rare Diseases

Foundation » grant.

\section{REFERENCES}

1. Hall JG (1981) An approach to congenital contractures (arthrogryposis). Pediatric annals 10 (7):15-26

2. Haliloglu G, Topaloglu H (2013) Arthrogryposis and fetal hypomobility syndrome. Handbook of clinical neurology 113:1311-1319. doi:10.1016/B978-0-444-59565-2.00003-4

3. Fahy MJ, Hall JG (1990) A retrospective study of pregnancy complications among 828 cases of arthrogryposis. Genetic counseling 1 (1):3-11

4. Hammond E, Donnenfeld AE (1995) Fetal akinesia. Obstetrical \& gynecological survey 50 (3):240-249

5. Pena SD, Shokeir MH (1974) Autosomal recessive cerebro-oculo-facio-skeletal (COFS) syndrome. Clin Genet 5 (4):285-293

6. Bamshad M, Van Heest AE, Pleasure D (2009) Arthrogryposis: a review and update. The Journal of bone and joint surgery American volume 91 Suppl 4:40-46. doi:10.2106/JBJS.I.00281

7. Navti OB, Kinning E, Vasudevan P, Barrow M, Porter H, Howarth E, Konje J, Khare M (2010) Review of perinatal management of arthrogryposis at a large UK teaching hospital serving a multiethnic population. Prenatal diagnosis 30 (1):49-56. doi:10.1002/pd.2411

8. Laquerriere A, Maluenda J, Camus A, Fontenas L, Dieterich K, Nolent F, Zhou J, Monnier N, Latour P, Gentil D, Heron D, Desguerres I, Landrieu P, Beneteau C, Delaporte B, Bellesme C, Baumann C, Capri Y, Goldenberg A, Lyonnet S, Bonneau D, Estournet B, Quijano-Roy S, Francannet C, Odent S, Saint-Frison MH, Sigaudy S, Figarella-Branger D, Gelot A, Mussini JM, Lacroix C, Drouin-Garraud V, Malinge MC, Attie-Bitach T, Bessieres B, Bonniere M, Encha-Razavi F, Beaufrere AM, Khung-Savatovsky S, Perez MJ, Vasiljevic A, Mercier S, Roume J, Trestard L, Saugier-Veber P, Cordier MP, Layet V, Legendre M, Vigouroux-Castera A, Lunardi J, Bayes M, Jouk PS, Rigonnot L, Granier M, Sternberg D, Warszawski J, Gut I, Gonzales M, Tawk M, Melki J (2014) Mutations in CNTNAP1 and ADCY6 are responsible for severe arthrogryposis multiplex congenita with axoglial defects. Human molecular genetics 23 (9):2279-2289. doi:10.1093/hmg/ddt618

9. Banker BQ (1986) Arthrogryposis multiplex congenita: spectrum of pathologic changes. Human pathology 17 (7):656-672

10. Vuopala K, Ignatius J, Herva R (1995) Lethal arthrogryposis with anterior horn cell disease. Human pathology 26 (1):12-19

11. Vuopala K, Makela-Bengs P, Suomalainen A, Herva R, Leisti J, Peltonen L (1995) Lethal congenital contracture syndrome (LCCS), a fetal anterior horn cell disease, is not linked to the SMA 5q locus. J Med Genet 32 (1):36-38

12. Devisme L, Bouchet C, Gonzales M, Alanio E, Bazin A, Bessieres B, Bigi N, Blanchet P, Bonneau D, Bonnieres M, Bucourt M, Carles D, Clarisse B, Delahaye S, Fallet-Bianco C, Figarella-Branger D, Gaillard D, Gasser B, Delezoide AL, Guimiot F, Joubert M, Laurent N, 
Laquerriere A, Liprandi A, Loget P, Marcorelles P, Martinovic J, Menez F, Patrier S,

364 Pelluard F, Perez MJ, Rouleau C, Triau S, Attie-Bitach T, Vuillaumier-Barrot S, Seta N, 365 Encha-Razavi F (2012) Cobblestone lissencephaly: neuropathological subtypes and

366 correlations with genes of dystroglycanopathies. Brain 135 (Pt 2):469-482. doi:10.1093/brain/awr357

13. Witters I, Moerman P, Fryns JP (2002) Fetal akinesia deformation sequence: a study of 30 consecutive in utero diagnoses. American journal of medical genetics 113 (1):23-28. doi:10.1002/ajmg.10698

14. Fallet-Bianco C, Laquerriere A, Poirier K, Razavi F, Guimiot F, Dias P, Loeuillet L, Lascelles K, Beldjord C, Carion N, Toussaint A, Revencu N, Addor MC, Lhermitte B, Gonzales M, Martinovich J, Bessieres B, Marcy-Bonniere M, Jossic F, Marcorelles P, Loget P, Chelly J, Bahi-Buisson N (2014) Mutations in tubulin genes are frequent causes of various foetal malformations of cortical development including microlissencephaly. Acta neuropathologica communications 2:69. doi:10.1186/2051-5960-2-69 15. Nogales E, Wolf SG, Downing KH (1998) Structure of the alpha beta tubulin dimer by electron crystallography. Nature 391 (6663):199-203. doi:10.1038/34465

379

380

381

382

383

384

385

386

387

388

389

390

391

392

393

394

395

396

397

398

399

400

401

402

403

404

405

406

407

408

16. Tian G, Huang Y, Rommelaere H, Vandekerckhove J, Ampe C, Cowan NJ (1996) Pathway leading to correctly folded beta-tubulin. Cell 86 (2):287-296. doi:S00928674(00)80100-2 [pii]

17. Tian G, Lewis SA, Feierbach B, Stearns T, Rommelaere H, Ampe C, Cowan NJ (1997) Tubulin subunits exist in an activated conformational state generated and maintained by protein cofactors. J Cell Biol 138 (4):821-832

18. Guihard-Costa AM, Larroche JC, Droulle P, Narcy F (1995) Fetal Biometry. Growth charts for practical use in fetopathology and antenatal ultrasonography. Introduction. Fetal diagnosis and therapy 10 (4):211-278

19. Kalampokas E, Kalampokas T, Sofoudis C, Deligeoroglou E, Botsis D (2012) Diagnosing arthrogryposis multiplex congenita: a review. ISRN obstetrics and gynecology 2012:264918. doi: $10.5402 / 2012 / 264918$

20. Chen CP (2012) Prenatal diagnosis and genetic analysis of fetal akinesia deformation sequence and multiple pterygium syndrome associated with neuromuscular junction disorders: a review. Taiwanese journal of obstetrics \& gynecology 51 (1):12-17. doi:10.1016/j.tjog.2012.01.004

21. Alkuraya FS, Cai X, Emery C, Mochida GH, Al-Dosari MS, Felie JM, Hill RS, Barry BJ, Partlow JN, Gascon GG, Kentab A, Jan M, Shaheen R, Feng Y, Walsh CA (2011) Human mutations in NDE1 cause extreme microcephaly with lissencephaly [corrected]. Am J Hum Genet 88 (5):536-547. doi:10.1016/j.ajhg.2011.04.003

22. Bakircioglu M, Carvalho OP, Khurshid M, Cox JJ, Tuysuz B, Barak T, Yilmaz S, Caglayan O, Dincer A, Nicholas AK, Quarrell O, Springell K, Karbani G, Malik S, Gannon C, Sheridan E, Crosier M, Lisgo SN, Lindsay S, Bilguvar K, Gergely F, Gunel M, Woods CG (2011) The essential role of centrosomal NDE1 in human cerebral cortex neurogenesis. Am J Hum Genet 88 (5):523-535. doi:10.1016/j.ajhg.2011.03.019

23. Hu WF, Pomp O, Ben-Omran T, Kodani A, Henke K, Mochida GH, Yu TW, Woodworth MB, Bonnard C, Raj GS, Tan TT, Hamamy H, Masri A, Shboul M, Al Saffar M, Partlow JN, Al-Dosari M, Alazami A, Alowain M, Alkuraya FS, Reiter JF, Harris MP, Reversade B, Walsh CA (2014) Katanin p80 regulates human cortical development by limiting centriole and cilia number. Neuron 84 (6):1240-1257. doi:10.1016/j.neuron.2014.12.017 
24. Kumar RA, Pilz DT, Babatz TD, Cushion TD, Harvey K, Topf M, Yates L, Robb S, Uyanik G, Mancini GM, Rees MI, Harvey RJ, Dobyns WB (2010) TUBA1A mutations cause wide spectrum lissencephaly (smooth brain) and suggest that multiple neuronal migration pathways converge on alpha tubulins. Human molecular genetics 19 (14):2817-2827

25. Cushion TD, Dobyns WB, Mullins JG, Stoodley N, Chung SK, Fry AE, Hehr U, Gunny R, Aylsworth AS, Prabhakar P, Uyanik G, Rankin J, Rees MI, Pilz DT (2013) Overlapping cortical malformations and mutations in TUBB2B and TUBA1A. Brain 136 (Pt 2):536-548. doi:10.1093/brain/aws338

26. Bahi-Buisson N, Poirier K, Fourniol F, Saillour Y, Valence S, Lebrun N, Hully M, Bianco CF, Boddaert N, Elie C, Lascelles K, Souville I, Consortium LI-T, Beldjord C, Chelly J (2014) The wide spectrum of tubulinopathies: what are the key features for the diagnosis? Brain 137 (Pt 6):1676-1700. doi:10.1093/brain/awu082

27. Tian G, Jaglin XH, Keays DA, Francis F, Chelly J, Cowan NJ (2010) Disease-associated mutations in TUBA1A result in a spectrum of defects in the tubulin folding and heterodimer assembly pathway. Human molecular genetics 19 (18):3599-3613

28. Jaglin XH, Chelly J (2009) Tubulin-related cortical dysgeneses: microtubule dysfunction underlying neuronal migration defects. Trends Genet 25 (12):555-566

29. Poirier K, Saillour Y, Bahi-Buisson N, Jaglin XH, Fallet-Bianco C, Nabbout R, Castelnau-Ptakhine L, Roubertie A, Attie-Bitach T, Desguerre I, Genevieve D, Barnerias C, Keren B, Lebrun N, Boddaert N, Encha-Razavi F, Chelly J (2010) Mutations in the neuronal ss-tubulin subunit TUBB3 result in malformation of cortical development and neuronal migration defects. Human molecular genetics 19 (22):4462-4473. doi:10.1093/hmg/ddq377

30. Saillour Y, Broix L, Bruel-Jungerman E, Lebrun N, Muraca G, Rucci J, Poirier K, Belvindrah R, Francis F, Chelly J (2013) Beta tubulin isoforms are not interchangeable for rescuing impaired radial migration due to Tubb3 knockdown. Human molecular genetics. doi: $10.1093 / \mathrm{hmg} / \mathrm{ddt} 538$

\section{LEGENDS TO THE FIGURES}

Figure 1: Macroscopical findings

A. Severe foetal akinesia sequence with multiple deformations, joint contractures and pterygia, along with severe global amyotrophy

B. Superior view of the brain exhibiting a cobblestone-like appearance with abnormal meningeal vessels 
C. Inferior view of the brain displaying absent interhemispheric fissure due to fusion of the

446 meninges, absent olfactory bulbs and tracts and severely hypoplastic cerebellum

447 D. With absent foliation and almost indiscernible vermis and cerebellar hemispheres.

$449 \quad$ Figure 2: Main histological lesions

450 A. Severe hypoplasia of the spinal cord (arrow) (H\& E stain, OMx25)

B. With at higher magnification, absent descending (arrow) and ascending tracts (triangle)

452 and no motoneurons in the anterior horns (H\& E stain, OMx250)

453

C. Global disorganization of the cerebral mantle with no recognizable cortical plate,

454 intermediate and germinal zones (H\& E stain, OMx25)

455 D. Calretinin immunohistochemistry showing aberrant Cajal Retzius cell location, with focal 456 accumulation of these cells along the persisting glia limitans instead of forming a continuous 457 streak located at the upper third of the molecular layer (OMx 100)

458 E. Microscopic view of the cortical plate displaying thickened leptomeninges with tortuous

459 vessels, only a minority of them properly penetrating into the brain parenchyma (arrow) (H\&

460 E stain, OMx 100)

461 F. Absent lamination of the cortical plate replaced by nodules or columns of neurons, some of

462 them overmigrating into the leptomeningeal spaces (arrow) (H\& E stain, OMx250)

464 Figure 3: Vimentin immunohistochemical studies

465 A. Irregular thickening of the meninges (OMx100)

466 B. Compared with an age-matched control brain (OMx100)

467 C. With immature neurons accumulating just under the fragmented glia limitans (arrow) and disorganized vascular network (OMx250)

D. With abnormal fibrous walls (arrow) and absent radial glia (OMx400) 
470 E. And paucity of radial glial cells( arrow) and fragmentation of the radial glia in the

471 subventricular zone $(\mathrm{OMx} 400)$

472 F. Compared to an age-matched control brain where the neuroepithelium (arrow) and the 473 subventricular zone are strongly immunolabeled (OMx400)

474 H\&E: Haematoxylin and eosin, OM: original magnification

476 Figure 4: TUBB2B de novo missense mutation (p.Cys239Phe) responsible of the phenotype 477 FADS with microlissencephaly.

478 A. Pedigree of the family and chromatograms showing the de novo occurrence of the 479 TUBB2B p.Cys239Phe mutation. Square, male; round, female; diamond, fetus. Black colour, 480 affected individual.

481 B. Evolution conservation of the p.Cys 239 amino acid in orthologues from stickleback to 482 human. C. Structural representation using Pymol software of the $\alpha / \beta$ heterodimer depicted 483 without (top left) or with (top right) surface delimitation. p.Cys239 amino acid (in green) is 484 localized into an helix inside the monomer but outside GTP, GDP and taxol binding sites 485 (detailed view, bottom). Pdb: 1TUB.

487 Figure 5: Defects in the $\alpha / \beta$ heterodimerisation process in the microtubule incorporation and 488 dynamical behaviour in COS7 and fibroblasts expressing the p.Cys239Phe mutation.

489 A. The p.Cys239Phe TUBB2B mutation results in inefficient $\alpha / \beta$ heterodimer formation in 490 vitro. Analysis by SDS-Page and non denaturing gel of in vitro translation products conducted 491 with $35 \mathrm{~S}$ methionine labeled wild type and p.Cys239Phe mutant. The reaction products were 492 further chased with bovine brain tubulin to generate $\alpha / \beta$ heterodimers. SDS-Page gel showed 493 that the mutant was translated as efficiently as the wild type control. Note that in non 494 denaturing gel condition, p.Cys239Phe mutant generated heterodimers in a diminished yield. 
B. Expression of C-terminal Flag tagged TUBB2B wild type (left column) and

496 p.Cys239Phe mutant (right column) in transfected COS7 cells revealed by antiflag (top line)

497 and $\alpha$-tubulin (bottom line) staining. Note that a part of p.Cys239Phe mutant proteins failed to

498 incorporate into the microtubule network, producing a more diffuse cytosolic labeling pattern

499 in comparison with WT TUBB2B.

500 C. In vivo analysis of cytoskeleton behaviour and stability using patient's fibroblasts from

501 amiotic liquid. Evaluation of the sensitivity of microtubules to cold treatment and of its ability

502 to repolymerize was analyzed in control fibroblasts and patient fibroblasts with p.Cys239Phe

503 mutation after $8 \mathrm{~min}$ of cold treatment at $4^{\circ} \mathrm{C}$ (left graph) or after $20 \mathrm{~min}$ at $4^{\circ} \mathrm{C}$ and 5 min at

$50437^{\circ} \mathrm{C}$ (right graph). Note that the fibroblasts of the fetus correctly reacted to cold treatment by

505 showing an increase in capacity to repolymerize compared to the wild type control.

506

507 Supplementary figures

508 Supplementary figure 1: US examination performed at $14 \mathrm{WG}$ showing fetal (A) retrognathia

509 and dilatation of the fourth cerebral ventricle (B)

510

511 Supplementary figure 2: Fetal examination displaying arthrogryposis with clenched hands 512 (A), posterior cleft palate (B), antebrachial C) and axillary pterygia (D). 
1. Hall JG (1981) An approach to congenital contractures (arthrogryposis). Pediatric annals 10 (7): $15-26$

2. Haliloglu G, Topaloglu H (2013) Arthrogryposis and fetal hypomobility syndrome. Handbook of clinical neurology 113:1311-1319. doi:10.1016/B978-0-444-59565-2.00003-4 3. Fahy MJ, Hall JG (1990) A retrospective study of pregnancy complications among 828 cases of arthrogryposis. Genetic counseling 1 (1):3-11

4. Hammond E, Donnenfeld AE (1995) Fetal akinesia. Obstetrical \& gynecological survey 50 (3):240-249

5. Pena SD, Shokeir MH (1974) Autosomal recessive cerebro-oculo-facio-skeletal (COFS) syndrome. Clin Genet 5 (4):285-293

6. Bamshad M, Van Heest AE, Pleasure D (2009) Arthrogryposis: a review and update. The Journal of bone and joint surgery American volume 91 Suppl 4:40-46. doi:10.2106/JBJS.I.00281

7. Navti OB, Kinning E, Vasudevan P, Barrow M, Porter H, Howarth E, Konje J, Khare M (2010) Review of perinatal management of arthrogryposis at a large UK teaching hospital serving a multiethnic population. Prenatal diagnosis 30 (1):49-56. doi:10.1002/pd.2411

8. Laquerriere A, Maluenda J, Camus A, Fontenas L, Dieterich K, Nolent F, Zhou J, Monnier N, Latour P, Gentil D, Heron D, Desguerres I, Landrieu P, Beneteau C, Delaporte B, Bellesme C, Baumann C, Capri Y, Goldenberg A, Lyonnet S, Bonneau D, Estournet B, Quijano-Roy S, Francannet C, Odent S, Saint-Frison MH, Sigaudy S, Figarella-Branger D, Gelot A, Mussini JM, Lacroix C, Drouin-Garraud V, Malinge MC, Attie-Bitach T, Bessieres B, Bonniere M, Encha-Razavi F, Beaufrere AM, Khung-Savatovsky S, Perez MJ, Vasiljevic A, Mercier S, Roume J, Trestard L, Saugier-Veber P, Cordier MP, Layet V, Legendre M, Vigouroux-Castera A, Lunardi J, Bayes M, Jouk PS, Rigonnot L, Granier M, Sternberg D, Warszawski J, Gut I, Gonzales M, Tawk M, Melki J (2014) Mutations in CNTNAP1 and ADCY6 are responsible for severe arthrogryposis multiplex congenita with axoglial defects. Human molecular genetics 23 (9):2279-2289. doi:10.1093/hmg/ddt618

9. Banker BQ (1986) Arthrogryposis multiplex congenita: spectrum of pathologic changes. Human pathology 17 (7):656-672

10. Vuopala K, Ignatius J, Herva R (1995) Lethal arthrogryposis with anterior horn cell disease. Human pathology 26 (1):12-19

11. Vuopala K, Makela-Bengs P, Suomalainen A, Herva R, Leisti J, Peltonen L (1995) Lethal congenital contracture syndrome (LCCS), a fetal anterior horn cell disease, is not linked to the SMA 5q locus. J Med Genet 32 (1):36-38

12. Devisme L, Bouchet C, Gonzales M, Alanio E, Bazin A, Bessieres B, Bigi N, Blanchet P, Bonneau D, Bonnieres M, Bucourt M, Carles D, Clarisse B, Delahaye S, Fallet-Bianco C, Figarella-Branger D, Gaillard D, Gasser B, Delezoide AL, Guimiot F, Joubert M, Laurent N, Laquerriere A, Liprandi A, Loget P, Marcorelles P, Martinovic J, Menez F, Patrier S, Pelluard F, Perez MJ, Rouleau C, Triau S, Attie-Bitach T, Vuillaumier-Barrot S, Seta N, Encha-Razavi F (2012) Cobblestone lissencephaly: neuropathological subtypes and correlations with genes of dystroglycanopathies. Brain 135 (Pt 2):469-482. doi:10.1093/brain/awr357

13. Witters I, Moerman P, Fryns JP (2002) Fetal akinesia deformation sequence: a study of 30 consecutive in utero diagnoses. American journal of medical genetics 113 (1):23-28. doi:10.1002/ajmg.10698

560 14. Fallet-Bianco C, Laquerriere A, Poirier K, Razavi F, Guimiot F, Dias P, Loeuillet L, 561 Lascelles K, Beldjord C, Carion N, Toussaint A, Revencu N, Addor MC, Lhermitte B, 
562 Gonzales M, Martinovich J, Bessieres B, Marcy-Bonniere M, Jossic F, Marcorelles P,

563 Loget P, Chelly J, Bahi-Buisson N (2014) Mutations in tubulin genes are frequent causes of

564 various foetal malformations of cortical development including microlissencephaly. Acta neuropathologica communications 2:69. doi:10.1186/2051-5960-2-69 15. Nogales E, Wolf SG, Downing KH (1998) Structure of the alpha beta tubulin dimer by electron crystallography. Nature 391 (6663):199-203. doi:10.1038/34465

568 16. Tian G, Huang Y, Rommelaere H, Vandekerckhove J, Ampe C, Cowan NJ (1996) Pathway leading to correctly folded beta-tubulin. Cell 86 (2):287-296. doi:S00928674(00)80100-2 [pii]

17. Tian G, Lewis SA, Feierbach B, Stearns T, Rommelaere H, Ampe C, Cowan NJ (1997) Tubulin subunits exist in an activated conformational state generated and maintained by protein cofactors. J Cell Biol 138 (4):821-832

574 18. Guihard-Costa AM, Larroche JC, Droulle P, Narcy F (1995) Fetal Biometry. Growth charts for practical use in fetopathology and antenatal ultrasonography. Introduction. Fetal diagnosis and therapy $10(4): 211-278$

19. Kalampokas E, Kalampokas T, Sofoudis C, Deligeoroglou E, Botsis D (2012) Diagnosing arthrogryposis multiplex congenita: a review. ISRN obstetrics and gynecology 2012:264918. doi: $10.5402 / 2012 / 264918$ 20. Chen CP (2012) Prenatal diagnosis and genetic analysis of fetal akinesia deformation sequence and multiple pterygium syndrome associated with neuromuscular junction disorders: a review. Taiwanese journal of obstetrics \& gynecology 51 (1):12-17. doi:10.1016/j.tjog.2012.01.004

585

586 21. Alkuraya FS, Cai X, Emery C, Mochida GH, Al-Dosari MS, Felie JM, Hill RS, Barry BJ, Partlow JN, Gascon GG, Kentab A, Jan M, Shaheen R, Feng Y, Walsh CA (2011) Human mutations in NDE1 cause extreme microcephaly with lissencephaly [corrected]. Am J Hum Genet 88 (5):536-547. doi:10.1016/j.ajhg.2011.04.003

588

589

590

591

22. Bakircioglu M, Carvalho OP, Khurshid M, Cox JJ, Tuysuz B, Barak T, Yilmaz S, Caglayan O, Dincer A, Nicholas AK, Quarrell O, Springell K, Karbani G, Malik S, Gannon C, Sheridan E, Crosier M, Lisgo SN, Lindsay S, Bilguvar K, Gergely F, Gunel M, Woods CG (2011) The essential role of centrosomal NDE1 in human cerebral cortex neurogenesis. Am J Hum Genet 88 (5):523-535. doi:10.1016/j.ajhg.2011.03.019

593 23. Hu WF, Pomp O, Ben-Omran T, Kodani A, Henke K, Mochida GH, Yu TW, Woodworth MB, Bonnard C, Raj GS, Tan TT, Hamamy H, Masri A, Shboul M, Al Saffar M, Partlow JN, Al-Dosari M, Alazami A, Alowain M, Alkuraya FS, Reiter JF, Harris MP, Reversade B, Walsh CA (2014) Katanin p80 regulates human cortical development by limiting centriole and cilia number. Neuron 84 (6):1240-1257. doi:10.1016/j.neuron.2014.12.017

24. Kumar RA, Pilz DT, Babatz TD, Cushion TD, Harvey K, Topf M, Yates L, Robb S, Uyanik G, Mancini GM, Rees MI, Harvey RJ, Dobyns WB (2010) TUBA1A mutations cause wide spectrum lissencephaly (smooth brain) and suggest that multiple neuronal migration pathways converge on alpha tubulins. Human molecular genetics 19 (14):2817-2827

25. Cushion TD, Dobyns WB, Mullins JG, Stoodley N, Chung SK, Fry AE, Hehr U, Gunny R, Aylsworth AS, Prabhakar P, Uyanik G, Rankin J, Rees MI, Pilz DT (2013) Overlapping cortical malformations and mutations in TUBB2B and TUBA1A. Brain 136 (Pt 2):536-548. doi:10.1093/brain/aws338

606 26. Bahi-Buisson N, Poirier K, Fourniol F, Saillour Y, Valence S, Lebrun N, Hully M, Bianco 607 CF, Boddaert N, Elie C, Lascelles K, Souville I, Consortium LI-T, Beldjord C, Chelly J 608 (2014) The wide spectrum of tubulinopathies: what are the key features for the diagnosis? 609 Brain 137 (Pt 6):1676-1700. doi:10.1093/brain/awu082 
610 27. Tian G, Jaglin XH, Keays DA, Francis F, Chelly J, Cowan NJ (2010) Disease-

611 associated mutations in TUBA1A result in a spectrum of defects in the tubulin folding and

612 heterodimer assembly pathway. Human molecular genetics 19 (18):3599-3613

613 28. Jaglin XH, Chelly J (2009) Tubulin-related cortical dysgeneses: microtubule dysfunction

614 underlying neuronal migration defects. Trends Genet 25 (12):555-566

615 29. Poirier K, Saillour Y, Bahi-Buisson N, Jaglin XH, Fallet-Bianco C, Nabbout R, 616 Castelnau-Ptakhine L, Roubertie A, Attie-Bitach T, Desguerre I, Genevieve D, Barnerias C, 617 Keren B, Lebrun N, Boddaert N, Encha-Razavi F, Chelly J (2010) Mutations in the neuronal 618 ss-tubulin subunit TUBB3 result in malformation of cortical development and neuronal 619 migration defects. Human molecular genetics 19 (22):4462-4473. doi:10.1093/hmg/ddq377

620 30. Saillour Y, Broix L, Bruel-Jungerman E, Lebrun N, Muraca G, Rucci J, Poirier K, 621 Belvindrah R, Francis F, Chelly J (2013) Beta tubulin isoforms are not interchangeable for 622 rescuing impaired radial migration due to Tubb3 knockdown. Human molecular genetics. 623 doi:10.1093/hmg/ddt538 

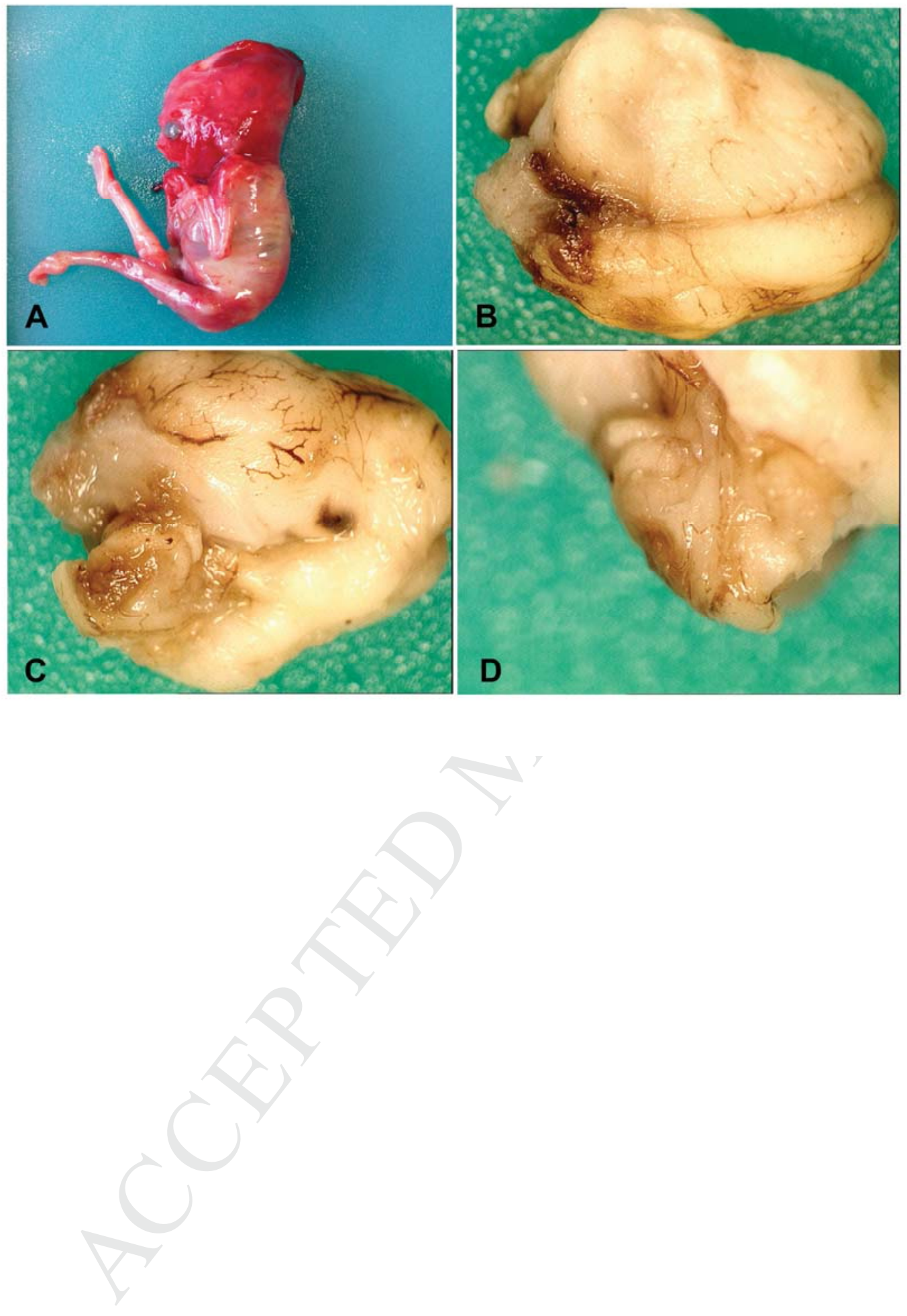

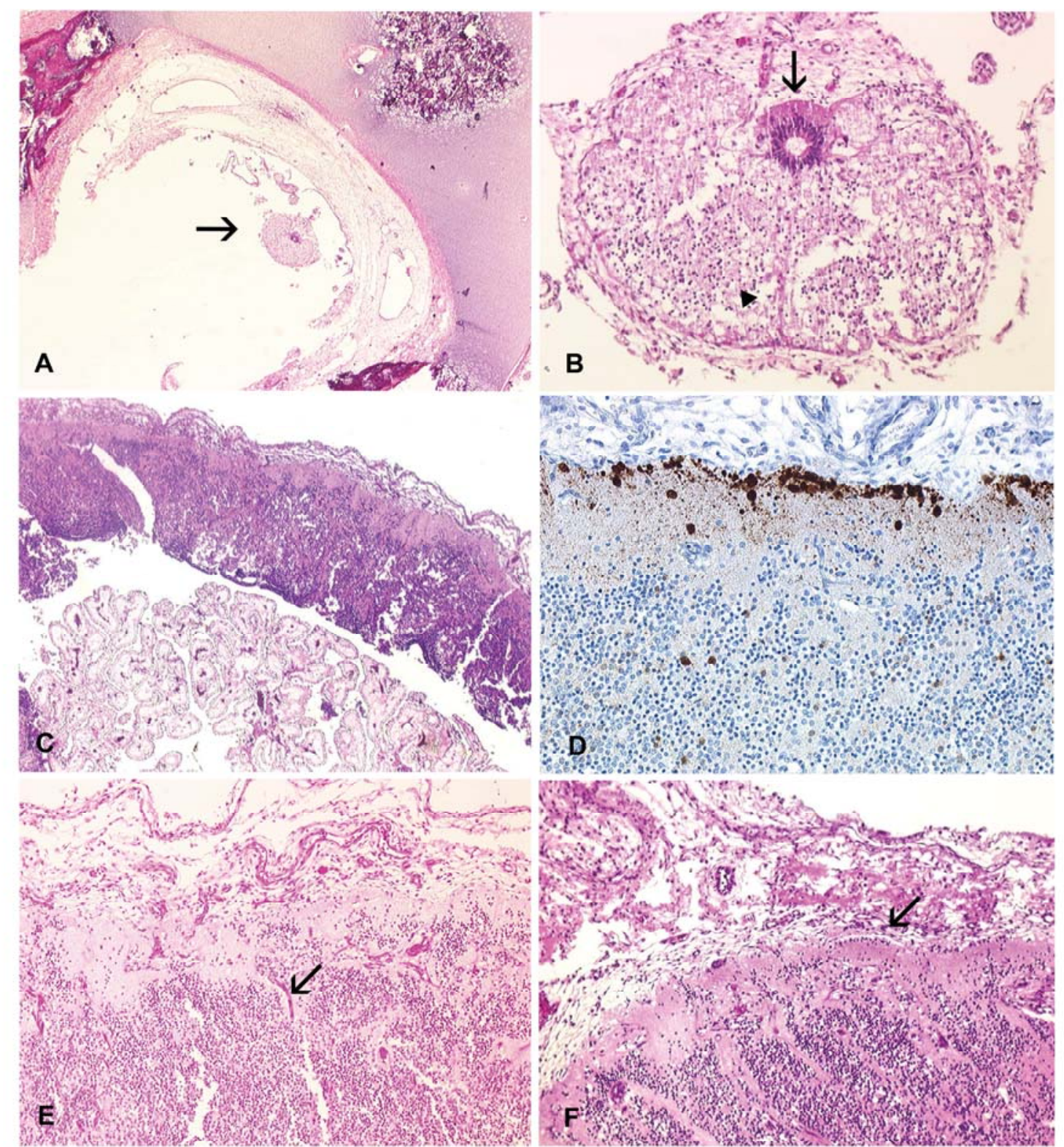


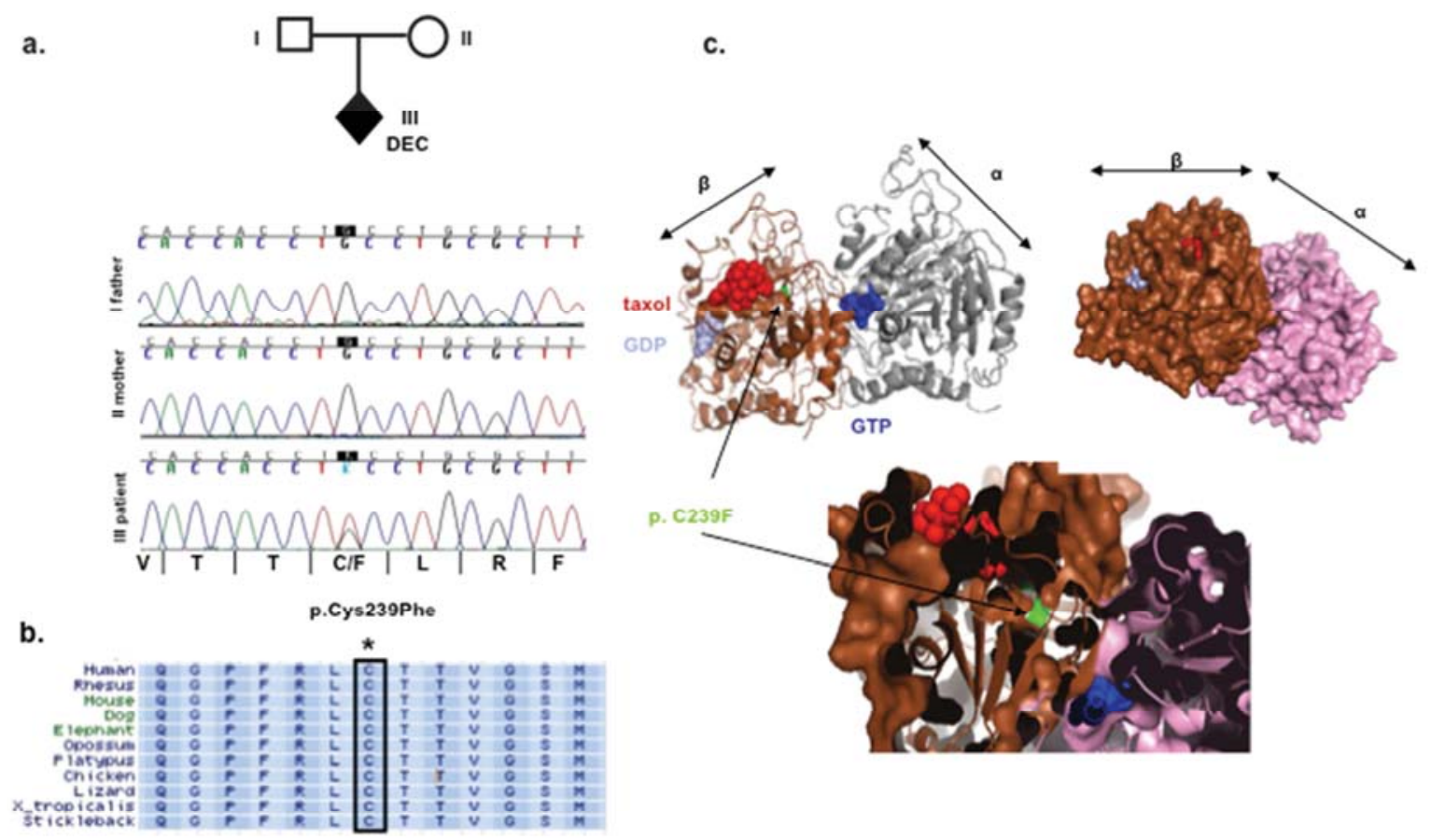

Figure 4 
A.

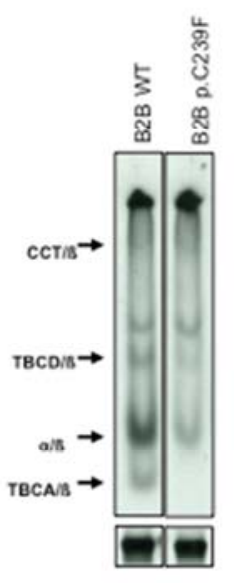

B.

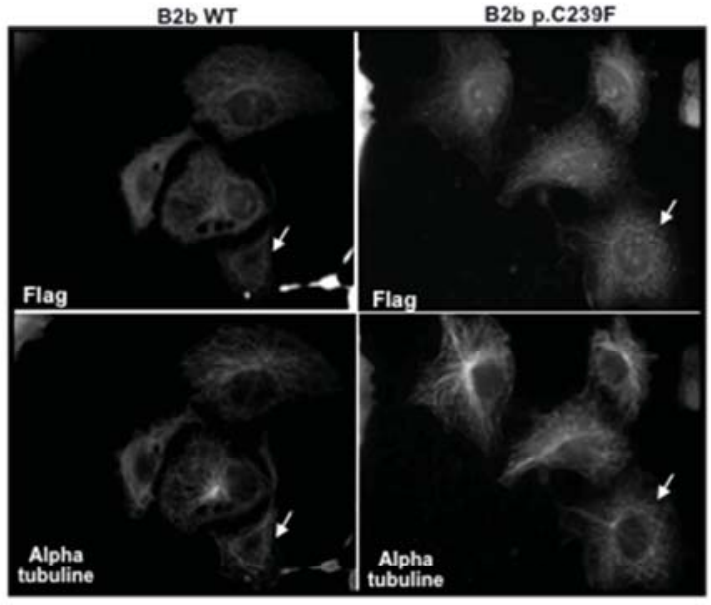

c.
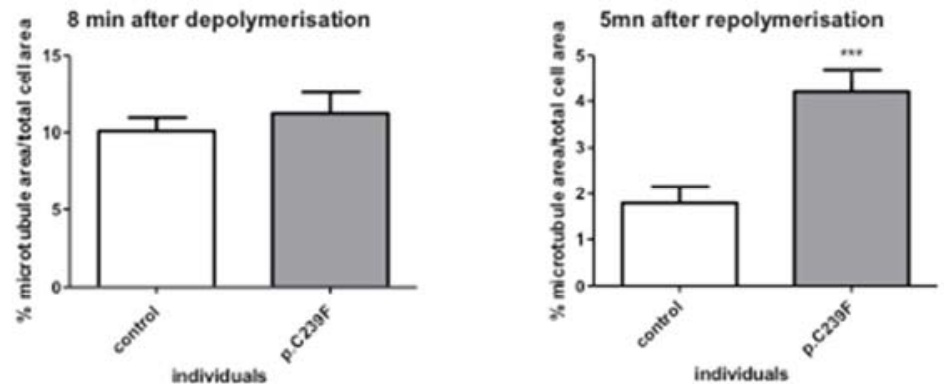


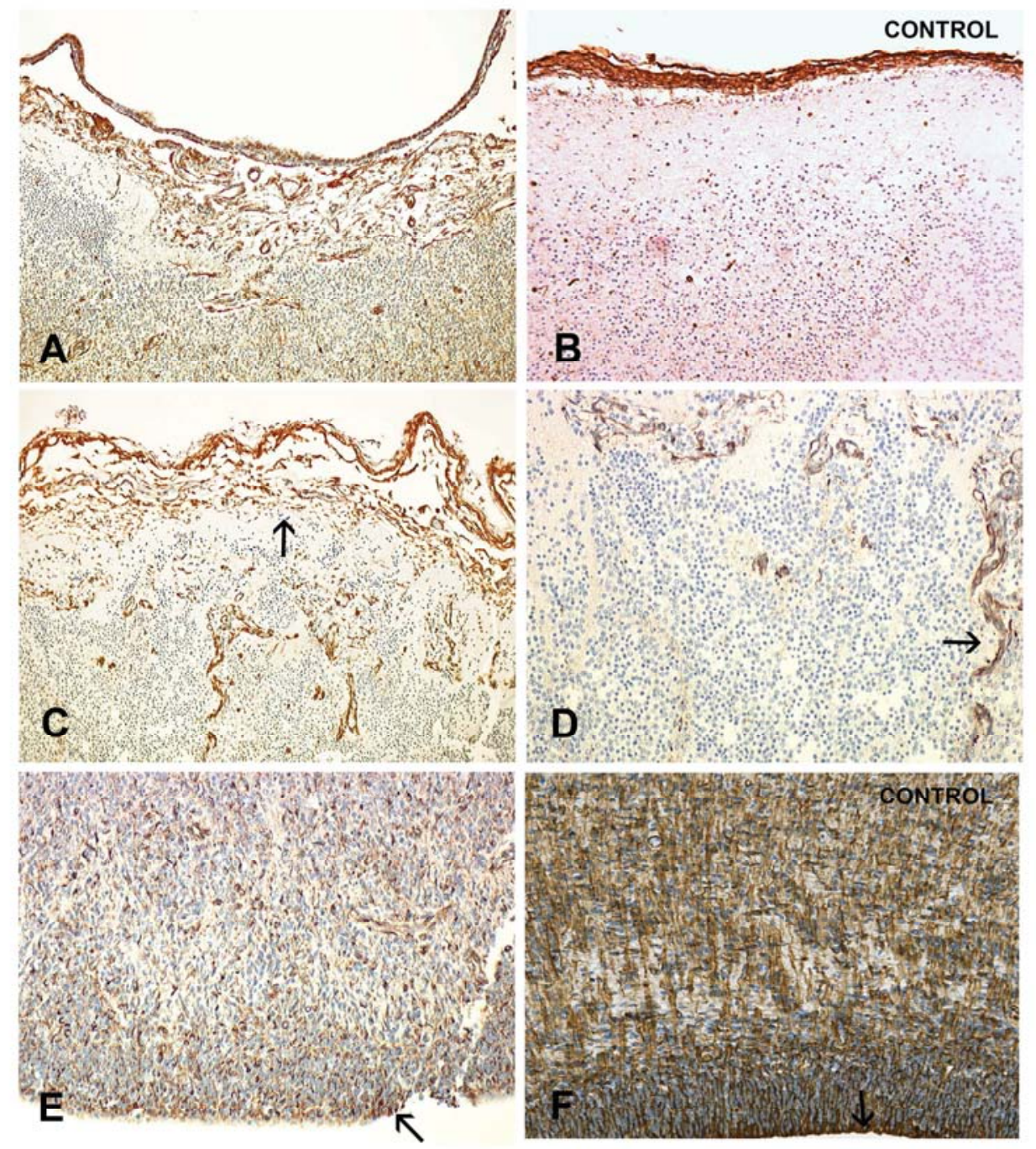

